\title{
Effects of long-term magnesium sulfate crystallisation tests on abrasion and durability of andesite aggregates
}

\author{
Balázs Czinder ${ }^{1}$ • Ákos Török ${ }^{1}$ (i) \\ Received: 31 January 2019 / Accepted: 13 August 2019 / Published online: 28 August 2019 \\ (C) The Author(s) 2019
}

\begin{abstract}
The durability of aggregates against salt weathering is calculated after five cycles of immersion in a magnesium sulfate solution followed by drying according to the relevant European standard (EN 1367-2: 2010). The aim of the study is to investigate the long-term durability of aggregates by increasing the number of cycles of the salt crystallization test from the standardized five to a maximum of 35. Three andesite types from Hungarian quarries were tested representing three different localities. The weight loss of the specimens was determined after every 5-cycle set. Results were documented for three size-fractions 10.0/11.2 mm, 11.2/ $14.0 \mathrm{~mm}$ and the $10.0 / 14.0 \mathrm{~mm}$, respectively. Relationships between immersion-drying cycles and magnesium sulfate values were described by the Pearson-coefficient. According to the test results, the magnesium sulfate values followed linearly increasing tendencies in the course of the long-term salt crystallization tests. Parallel to the salt-weathering tests, the changes in the mechanical properties of the salt-attacked aggregates were also detected by micro-Deval tests (EN 1097-1: 2012). The changes in micro-Deval coefficients were calculated in the form of a decay factor as a function of sulfate cycles. The results suggest that the micro-Deval coefficient does not rise after a certain salt cycle; i.e. higher number of salt-crystallisation cycles does not necessarily reduce the micro-Deval coefficient of studied andesite lithologies.
\end{abstract}

Keywords Andesite $\cdot$ Magnesium sulfate $\cdot$ Long-term crystallisation tests $\cdot$ Micro-Deval test $\cdot$ Durability

\section{Introduction}

Durability and weathering properties of crushed stone significantly control the use of these construction materials. Various methods have been developed to determine the resistance of aggregates to the different environmental and mechanical impacts. According to the relevant European standard weathering durability of aggregates should be determined by magnesium sulfate tests (EN 1367-2: 2010). This standard intends to model the weathering effect, provided by growing crystals exerting pressure onto the pore walls using magnesium salt rather than ice crystals (freeze-thaw). For the cylindrical test specimens, crystallisation related durability can be assessed by standardised freeze-thaw tests (EN 12371: 2010), where ice crystals are forming in the pores of the stone material (Piasta et al. 2016).

Ákos Török

torokakos@mail.bme.hu

1 Faculty of Civil Engineering, Department of Engineering Geology and Geotechnics, Budapest University of Technology and Economics, Budapest, Hungary
The sulfate tests are based on a similar principle (Yavuz et al. 2006; Ioannou et al. 2013). After the specimens are immersed in sulfate solution for a longer period, then they should be dried in an oven to conduce the growth of the sulfate crystals. Both sodium $\left(\mathrm{Na}_{2} \mathrm{SO}_{4}\right)$ and magnesium sulfate $\left(\mathrm{MgSO}_{4}\right)$ can be used. As both sulfates are extremely damaging salts (Ruiz-Agudo et al. 2007), the destructive effect of the crystals is greater than the effect of the ice crystals. The viscosity of the sodium sulfate solution is less than the magnesium sulfate's viscosity. The $\mathrm{Na}_{2} \mathrm{SO}_{4}$ can be absorbed in greater depth than $\mathrm{MgSO}_{4}$, but the crystallization pressure of sodium sulfate crystal is lower (La Iglesia et al. 1997). According to Ioannou et al. (2013) the magnesium sulfate soundness was greater than the sodium sulfate soundness of limestone and diabase aggregates. On the other hand, Ruiz-Agudo et al. (2007) measured greater weight loss in the case of sodium sulfate tests with a porous limestone type. For the determination of the weathering properties of aggregates, the European norm (EN 1367-2: 2010) requires the performance of the magnesium sulfate test, while the weathering properties of aggregates cannot be analysed by sodium sulfate. 
Fig. 1 Location of the quarries of the studied andesites:

Nógrádkövesd (Andesite-1), Recsk (Andesite-2) and Komló (Andesite-3)

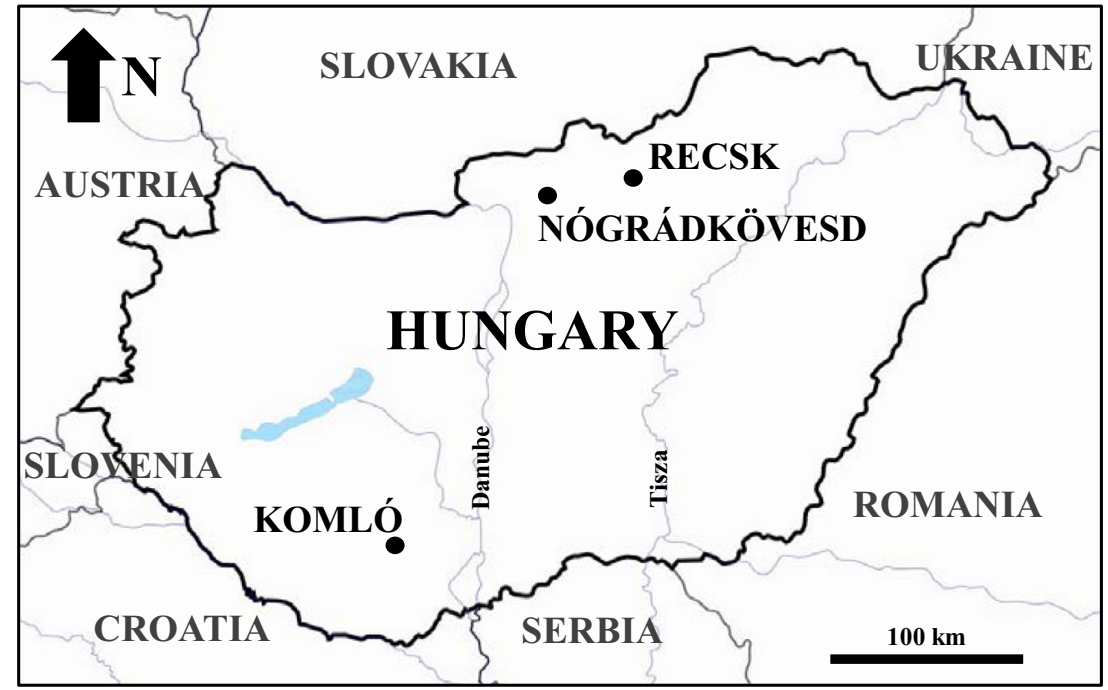

The weathering impacts can influence the mechanical and physical properties of the studied materials, including stones, mortars (Přikryl 2013; Wongprachum et al. 2018) or concretes (Muthusamy et al. 2015). The alteration of a chosen $X$ characteristics can be described by the decay factor $\left(\lambda_{X}\right)$ :

$\lambda_{X}=\left|\frac{X_{\text {sub }}-X_{0}}{X_{0}} \cdot 100\right|$

where $X_{0}$ is the previously determined reference value of the studied $X$ parameter, and $X_{\text {sub }}$ is the measured value of the studied parameter collected after the subjection of the specimens. The determination of the decay factor is suggested by different standards (e.g. EN 12371: 2010, where decay factor is determined according to the modulus of elasticity and called percentage decrease in elastic modulus; EN 1367-1: 2007, where decay factor is determined according the Los Angeles values and called percentage strength loss). The general form of the factor is represented in Eq. 1. Both rock mechanical and aggregate properties can be analysed this way. Ghobady and Babazadeh (2015) investigated Tertiary sandstones, and they determined the point load strength, the Brazilian tensile strength, the P Wave velocity loss and the slake durability index of the studied materials after freeze-thaw and salt crystallization tests. A decay function model was proposed and later verified through laboratory tests (Mutlutürk et al. 2004). This study describes the integrity loss process and the decay of the mechanical properties of rocks subjected to freezing-thawing and heating-cooling cycles.

Several test methods are developed to provide information on the durability, serviceability (Prrikryl 2017) and long-term performance of aggregates, such as the Los Angeles test (Cuelho et al. 2008; Török 2015; Ajalloeian and Kamani 2017), the Nordic test (Krutilová and Přikryl 2017), the slake durability test (Ghobadi and Babazadeh 2015; Miščević and Vlastelica 2011) or the micro-Deval test (Török and Czinder 2017). The comparison of the weathering and the durability properties showed various correspondence, and the $R^{2}$ values of the micro-Deval versus magnesium sulfate value plots changed between 0.1 and 0.7 (Phillips 2000; Cooley and James 2003; Cuelho et al. 2008).

The present paper focuses on the weathering and mechanical properties of andesites. Andesite was selected because this lithotype is one of the most widely applied stones as aggregate in the construction industry. The favourable mechanical and weathering properties make andesite suitable in road construction (Xie et al. 2016), in railway construction (Gálos and Kárpáti 2007) and in hydraulic engineering constructions (Özden and Topal 2009). The main aim of these tests is to assess the longterm changes in magnesium sulfate values, by increasing the salt crystallisation cycles from the standardised five cycles to 35 cycles. The changes in material properties were also assessed by micro-Deval tests after every
Table 1 Abbreviation, brief description and micro-fabric of the studied andesites

\begin{tabular}{llll}
\hline Name & Locality & Description & Micro-fabric \\
\hline Andesite-1 & Nógrádkövesd & $\begin{array}{c}\text { andesite with large plagioclase } \\
\text { phenocryst } \\
\text { slightly silicified pyroxene andesite } \\
\text { andesite-2 }\end{array}$ & $\begin{array}{l}\text { Recsk } \\
\text { porphyritic slightly intersertal basaltic } \\
\text { andesite } \\
\text { porphyritic intersertal } \\
\text { porphyritic intersertal }\end{array}$ \\
\hline
\end{tabular}



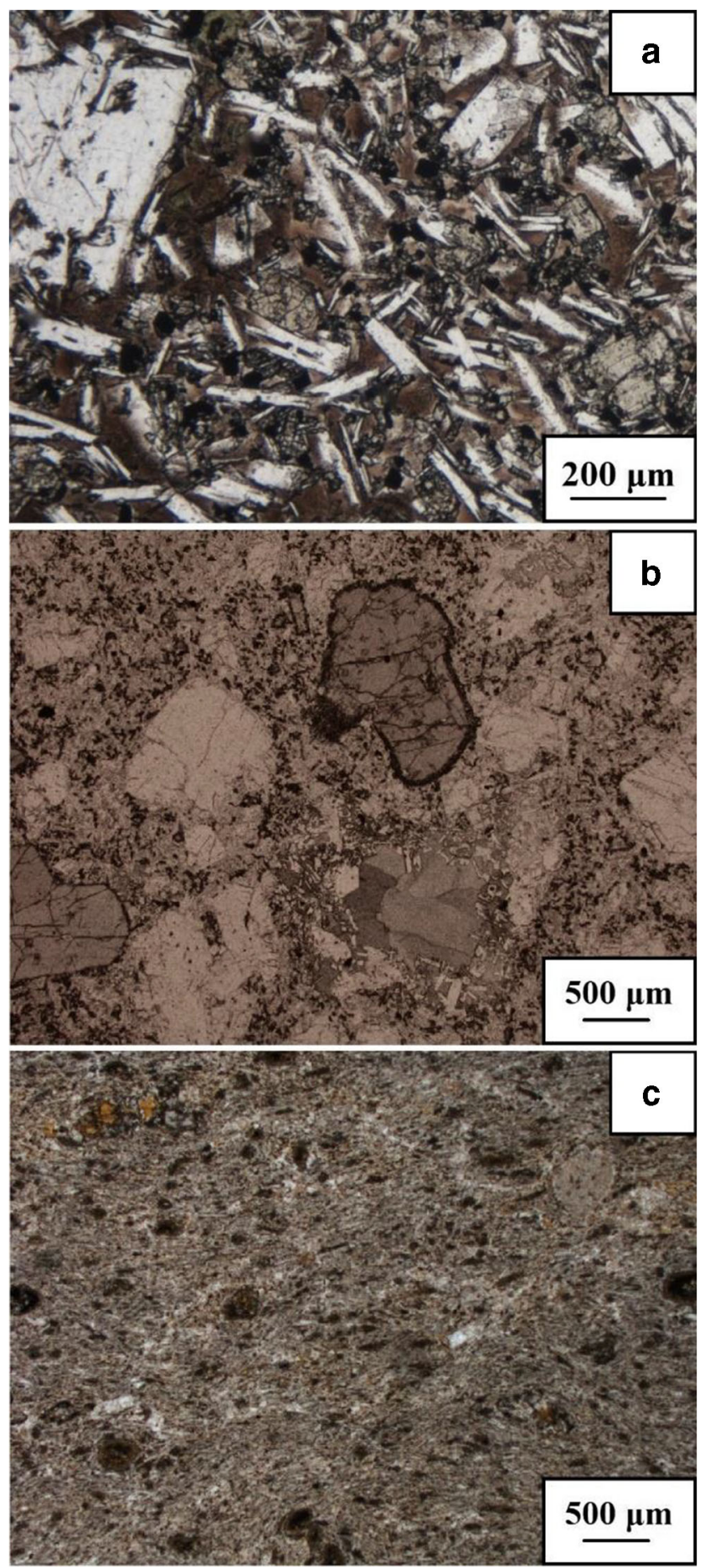

Fig. 2 Thin sections micrographs of the studied andesites: a) plagioclase laths and few amphiboles in the Andesite-1; b) Pyroxene crystals and larger plagioclases in Andesite-2; c) flow banded micro-fabric with small plagioclase and amphibole crystals in the glassy groundmass of Andesite3

five cycles. A correlation is outlined between magnesium sulfate values and salt crystallisation cycles. In addition, micro-Deval values and magnesium sulfate values as a function of sulfate cycles were also analysed.

\section{Materials}

Andesites from three quarries were used to investigate the long-term weathering properties. All three quarries are located in Hungary, in Nógrádkövesd (Cserhát Mountains), Recsk (Mátra Mountains) and Komló (Mecsek Mountains) (Fig. 1). All studied and quarried andesites were formed in the Miocene period (Haas 2013). The andesites represent three different lithotypes (Table 1). Andesite-1 is a typical amphibole andesite with plagioclase phenocrysts (Fig. 2). Plagioclase laths prevail in the texture with smaller amount of amphiboles and opaque minerals in the glassy groundmass. It also contains a small amount of pyroxene crystals. The amphibole and pyroxene crystals are relatively small with crystal sizes of $0.1-0.2 \mathrm{~mm}$. The palgioclase crystals form the framework and represent more than $50 \%$ of the texture providing a basaltic intersertal micro-fabric. Glassy groundmass is also observed in between phenocryst. Andesite- 2 is a slightly silicified pyroxene andesite from Recsk. The microfabric is characterized by a large amount of small plagioclase crystals that are found in the glassy matrix, while larger phenocrysts are mostly represented by pyroxene (mm-size). The slicification is related to minor hydrothermal alteration processes. Besides the prevailing palagioclase and pyroxene crystals, the andesite also contains a small amount of secondary minerals, such as calcite and limonite. A detailed description of the andesite is given by Cserny et al. 2004. Grey amphibole andesite is the third studied lithotype (Andesite-3) from Southern Hungary (Komló). It is characterized by the presence of a few plagioclase crystals and a minor amount of pyroxene in the prevailingly glassy groundmass (Klespitz 2012). The elongated plagioclase crystals are relatively small with length of $100-150 \mu \mathrm{m}$ and width of $15-30 \mu \mathrm{m}$. The amphibole crystals are visible as elongated 1-2 mm-long crystals. They show some alterations especially at crystal margins in the form of opaque zone. Small pehocrystals of pyroxene and a minor amount of magnetite are also found in the thinsections. The flow banding is a common feature of this andesite (Fig. 2).

The bulk density (in dry and water saturated conditions) and the water absorption of the studied andesites are collected in Table 2.

\section{Test methods}

The magnesium sulfate and the micro-Deval tests require aggregate samples with 10/14 mm-sized grains. The samples were prepared by crushing and sieving coarser grained aggregates and rock blocks. The relevant European standard (EN 1367-2: 2010) prescribes the application of a saturated solution of magnesium sulfate $\left(\mathrm{MgSO}_{4} \cdot 7 \mathrm{H}_{2} \mathrm{O}\right.$ solution) for the test. The standardized test method requires five cycles with the 
Table 2 Bulk density and water absorption of the studied andesites

\begin{tabular}{llll}
\hline Name & $\begin{array}{l}\text { Bulk density } \\
(\text { dry condition) } \\
{\left[\mathrm{kg} / \mathrm{m}^{3}\right]}\end{array}$ & $\begin{array}{l}\text { Bulk density } \\
(\text { water saturated condition }) \\
{\left[\mathrm{kg} / \mathrm{m}^{3}\right]}\end{array}$ & $\begin{array}{l}\text { Water } \\
\text { absorption } \\
{[\mathrm{m} \%]}\end{array}$ \\
\hline Andesite-1 & 2710 & 2735 & 0.91 \\
Andesite-2 & 2714 & 2730 & 0.46 \\
Andesite-3 & 2535 & 2579 & 1.51 \\
\hline
\end{tabular}

steps of Fig. 3. The magnesium sulfate crystals form in the drying phase (Fig. 4).

After the 5th cycle, the samples should be washed and sieved on the $10 \mathrm{~mm}$ sieve. The result of the test is a mass reduction value called magnesium sulfate value $(M S)$ in percentage by mass:

$M S=\frac{M_{1}-M_{2}}{M_{1}} \cdot 100$

where $M_{1}$ is the initial mass and $M_{2}$ is the final mass of the aggregate specimen retained on the $10 \mathrm{~mm}$ sieve.

For the investigation of the long-term properties, the test procedure was repeated seven times; that is, 35 cycles of immersion and drying were repeated. The mass reduction was measured and the magnesium sulfate value was obtained after every 5-cycle period. For the further laboratory tests, the fractions of $10.0 / 11.2 \mathrm{~mm}$ and the 11.2 / $14.0 \mathrm{~mm}$ sized grains were separated and measured. The fraction of 11.2/14.0 $\mathrm{mm}$ was sieved both on the 10 and $11.2 \mathrm{~mm}$ sieve. The test result after $n$ cycles is the longterm magnesium sulfate value.

Correlation and regression analyses were used to characterize the mass reduction of the sample in the course of the long-term tests. The relationship between the number of immersion-drying cycles and the magnesium sulfate values were described by the Pearson-coefficient $\left(R^{2}\right)$.

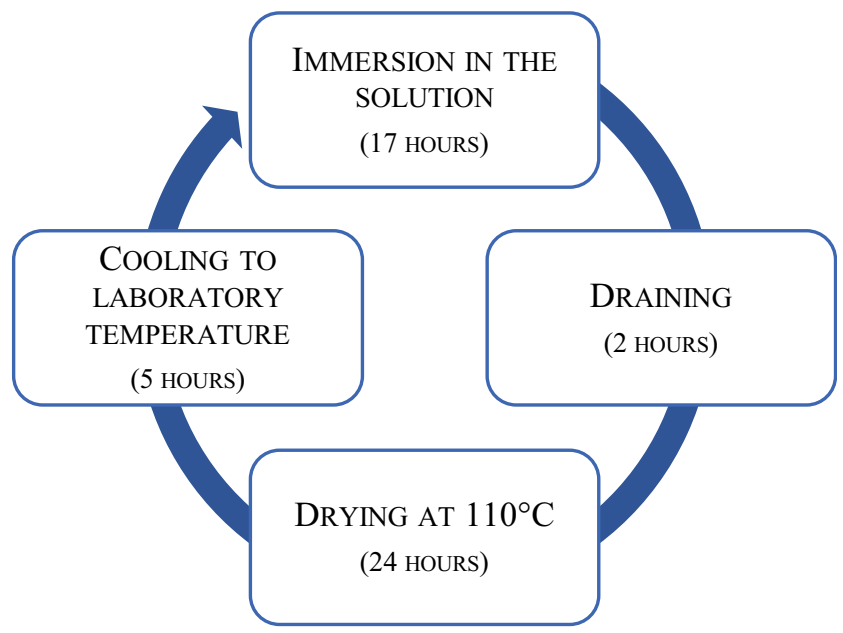

Fig. 3 One cycle of the magnesium sulfate test
The constant members of the calculated functions were missed, because the initial point in the Origin (which means the 0th cycle) was considered as a fixed point of the fitted curves.

The durability of the andesite samples was analysed by the micro-Deval test, which is used to investigate the resistance to abrasion (relevant standard: EN 1097-1: 2012). The aggregate samples should be formed from $150 \mathrm{~g}$ of $10.0 / 11.2 \mathrm{~mm}$ and $350 \mathrm{~g}$ of $11.2 / 14.0 \mathrm{~mm}$-sized grains. The samples were tested in steel drums (diameter: $200 \mathrm{~mm}$, height: $154 \mathrm{~mm}$ ), which were rotated by 12,000 times (100 rotations/min). The abrasive impact was increased by $5000 \mathrm{~g}$ of steel balls (diameter: $10 \mathrm{~mm}$ ) and 2.51 of water was added in the drum. After the required rotations, the samples were washed and sieved on a $1.6 \mathrm{~mm}$ sieve. The test result is the micro-Deval coefficient $\left(M_{D E}\right)$ in percentage by mass:

$M_{D E}=\frac{m_{1}-m_{2}}{m_{1}} \cdot 100$

where $m_{1}$ is the initial mass and $m_{2}$ is the final mass of the aggregate specimen retained on the $1.6 \mathrm{~mm}$ sieve. The micro-Deval coefficient of the studied andesite aggregates was determined after every 5 -cycle period. The tests were

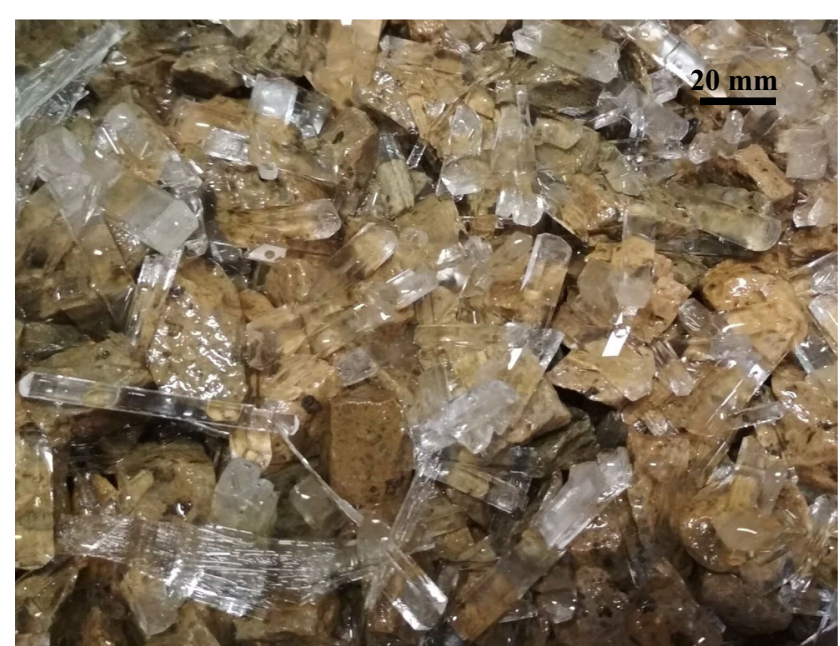

Fig. 4 Magnesium sulfate crystals on the grains of the aggregate sample of Andesite-2 (scale bar is on the right top) 
Table 3 The mass of the samples measured after the sulfate tests

\begin{tabular}{|c|c|c|c|c|c|c|c|c|c|c|}
\hline \multirow[t]{2}{*}{ Number of cycles } & \multirow[t]{2}{*}{ Fractions } & \multicolumn{3}{|l|}{ Andesite-1 } & \multicolumn{3}{|l|}{ Andesite-2 } & \multicolumn{3}{|c|}{ Andesite-3 } \\
\hline & & $\begin{array}{l}\mathrm{M}_{1} \\
{[\mathrm{~g}]}\end{array}$ & $\begin{array}{l}M_{2, g}>10.0 \\
{[\mathrm{~g}]}\end{array}$ & $\begin{array}{l}\mathrm{M}_{2, \mathrm{~g}>11.2} \\
{[\mathrm{~g}]}\end{array}$ & $\begin{array}{l}\mathrm{M}_{1} \\
{[\mathrm{~g}]}\end{array}$ & $\begin{array}{l}M_{2, g}>10.0 \\
{[\mathrm{~g}]}\end{array}$ & $\begin{array}{l}M_{2, g}>11.2 \\
{[\mathrm{~g}]}\end{array}$ & $\begin{array}{l}\mathrm{M}_{1} \\
{[\mathrm{~g}]}\end{array}$ & $\begin{array}{l}M_{2, g}>10.0 \\
{[\mathrm{~g}]}\end{array}$ & $\begin{array}{l}\mathrm{M}_{2, \mathrm{~g}}>11.2 \\
{[\mathrm{~g}]}\end{array}$ \\
\hline \multirow[t]{2}{*}{5} & $10.0 / 11.2$ & 3608.69 & 3546.56 & - & 3732.85 & 3680.64 & - & 4075.66 & 3808.05 & - \\
\hline & $11.2 / 14.0$ & $10,309.55$ & $10,286.74$ & $10,190.38$ & $10,217.58$ & $10,211.18$ & $10,090.27$ & 9380.32 & 9314.49 & 9095.50 \\
\hline \multirow[t]{2}{*}{10} & $10.0 / 11.2$ & 3246.36 & 3223.23 & - & 3380.59 & 3307.64 & - & 3508.00 & 2941.76 & - \\
\hline & $11.2 / 14.0$ & 9490.28 & 9434.82 & 9397.45 & 9389.92 & 9362.71 & 9250.59 & 8395.15 & 7762.88 & 7393.97 \\
\hline \multirow[t]{2}{*}{15} & $10.0 / 11.2$ & 2922.96 & 2869.49 & - & 3007.20 & 2935.63 & - & 2641.54 & 2152.01 & - \\
\hline & $11.2 / 14.0$ & 8697.46 & 8656.13 & 8591.60 & 8550.72 & 8532.56 & 8426.43 & 6693.98 & 6626.34 & 6199.71 \\
\hline \multirow[t]{2}{*}{20} & $10.0 / 11.2$ & 2569.41 & 2518.50 & - & 2635.43 & 2574.86 & - & 1851.61 & 1512.77 & - \\
\hline & $11.2 / 14.0$ & 7891.50 & 7837.95 & 7783.13 & 7726.50 & 7700.54 & 7639.57 & 5499.87 & 5253.61 & 4914.23 \\
\hline \multirow[t]{2}{*}{25} & $10.0 / 11.2$ & 2218.29 & 2202.59 & - & 2274.55 & 2227.38 & - & 1212.29 & 857.43 & - \\
\hline & $11.2 / 14.0$ & 7083.16 & 7008.97 & 6957.28 & 6939.72 & 6913.28 & 6867.61 & 4214.07 & 3896.63 & 3555.03 \\
\hline \multirow[t]{2}{*}{30} & $10.0 / 11.2$ & 1902.19 & 1849.48 & - & 1926.84 & 1901.43 & - & 707.15 & 527.53 & - \\
\hline & $11.2 / 14.0$ & 6257.40 & 6229.33 & 6156.24 & 6168.07 & 6146.18 & 6104.53 & 3205.31 & 3009.80 & 2736.31 \\
\hline \multirow[t]{2}{*}{35} & $10.0 / 11.2$ & 1549.32 & 1519.22 & - & 1601.05 & 1580.19 & - & 377.27 & 308.45 & - \\
\hline & $11.2 / 14.0$ & 5456.23 & 5416.79 & 5381.70 & 5404.63 & 5392.94 & 5369.88 & 2386.52 & 2296.15 & 2163.38 \\
\hline
\end{tabular}

$\left(M_{1}\right.$ : the initial mass of the sample; $M_{2, g}>10.0$ : the final mass of the sample with grains, which are larger than $10.0 \mathrm{~mm} ; M_{2, g}>11.2$ : the final mass of the sample with grains, which are larger than $11.2 \mathrm{~mm}$ )

made in pairs, and the average values were used for the subsequent analyses.

According to the micro-Deval test results, the decay factor of the resistance to abrasion $\left(\lambda_{M D E, i}\right)$ was calculated in percentage:

$\lambda_{M D E, i}=\left|\frac{M_{D E, i}-M_{D E, 0}}{M_{D E, 0}} \cdot 100\right|$

where $M_{D E, 0}$ is the reference micro-Deval coefficient (determined before the long-term magnesium sulfate test) and $M_{D E, i}$ is the micro-Deval coefficient determined after $i$ cycles of the sulfate test.

\section{Results}

The test results of the 10.0/11.2 $\mathrm{mm}$ and the $11.2 / 14.0 \mathrm{~mm}$ fractions were evaluated separately. The measured raw values are collected in Table 3. The mass reduction of the total 10.0/14.0 mm grain sized aggregate sample was also calculated (Table 4).

The data sets of the measured magnesium sulfate values are represented according to the number of immersion-drying cycles (Figs. 5, 6, and 7). The test results of the 10.0/11.2 mm, $11.2 / 14.0 \mathrm{~mm}$ and the $10.0 / 14.0 \mathrm{~mm}$-sized part were signed with blue, red and black colours. According to the magnesium sulfate test results, the $N_{M S}$ versus $M S$ plots follow a linear

Table 4 Magnesium sulfate test results

\begin{tabular}{|c|c|c|c|c|c|c|c|c|c|}
\hline \multirow{4}{*}{$\begin{array}{l}\text { Number of cycles } \\
\left(\mathrm{N}_{\mathrm{MS}}\right)^{[-]}\end{array}$} & \multicolumn{9}{|c|}{ Magnesium sulfate value } \\
\hline & \multicolumn{9}{|l|}{ (MS) $[\mathrm{m} \%]$} \\
\hline & \multicolumn{3}{|l|}{ Andesite-1 } & \multicolumn{3}{|l|}{ Andesite-2 } & \multicolumn{3}{|l|}{ Andesite-3 } \\
\hline & $10.0 / 11.2$ & $11.2 / 14.0$ & $10.0 / 14.0$ & $10.0 / 11.2$ & $11.2 / 14.0$ & $10.0 / 14.0$ & $10.0 / 11.2$ & $11.2 / 14.0$ & $10.0 / 14.0$ \\
\hline 0 & 0.0 & 0.0 & 0.0 & 0.0 & 0.0 & 0.0 & 0.0 & 0.0 & 0.0 \\
\hline 5 & 1.7 & 1.2 & 0.6 & 1.4 & 1.2 & 0.3 & 6.6 & 3.0 & 2.5 \\
\hline 10 & 2.4 & 2.1 & 1.2 & 3.5 & 2.7 & 1.1 & 21.6 & 14.6 & 12.3 \\
\hline 15 & 4.2 & 3.3 & 2.0 & 5.8 & 4.1 & 1.8 & 36.2 & 20.9 & 17.5 \\
\hline 20 & 6.1 & 4.6 & 3.0 & 8.0 & 5.2 & 2.6 & 47.8 & 29.3 & 24.1 \\
\hline 25 & 6.8 & 6.3 & 3.9 & 9.9 & 6.2 & 3.4 & 63.1 & 40.4 & 33.5 \\
\hline 30 & 9.4 & 7.9 & 4.9 & 11.1 & 7.2 & 4.0 & 72.5 & 49.1 & 39.9 \\
\hline 35 & 11.1 & 9.1 & 5.8 & 12.2 & 7.8 & 4.4 & 77.5 & 53.9 & 43.3 \\
\hline
\end{tabular}


Fig. 5 The long-term magnesium sulfate crystallisation tests of Andesite-1

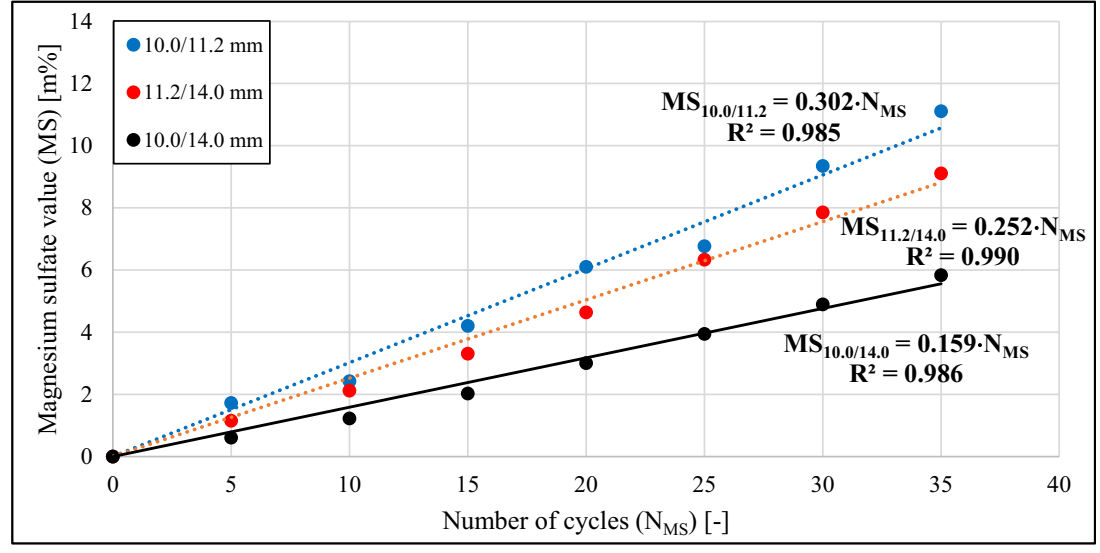

trend. The $R^{2}$ values of the fitted lines exceeded 0.98 in all cases.

The results of the micro-Deval tests are summarized in Table 5 and Fig. 8. Significant differences were observed as the number of cycles increased, e.g. the reference $M_{D E}$ value of Andesite-3 was 14.65, while after ten immersion-drying cycles it almost reached the value of 20 . In the case of Andesite-2, the alteration is negligible.

The greatest magnesium sulfate values were determined on the fraction of $10.0 / 11.2 \mathrm{~mm}$ in all cases; relatively more grains will weather under the lower merge of a studied fraction in the case of a narrower fraction, presuming uniform grain size distribution and uniform weathering in an aggregate fraction. In addition, the magnesium sulfate solution produces its fracturing effect near the surface of the grains in the case of stones with compact texture, and the reduction of the grain size increases the relative area of the surface. The $M S$ value of the fractions of $10.0 / 14.0 \mathrm{~mm}$ is less than the fractions of 11.2 / $14.2 \mathrm{~mm}$, because in this case the weight loss is calculated according to the mass of the grains, which are smaller than $10 \mathrm{~mm}$; i.e. not the grains that are smaller than $11.2 \mathrm{~mm}$.

The results of the complete 10.0/14.0 mm sized samples are shown in Fig. 9. The long-term magnesium sulfate tests revealed significant differences between Andesite-3 and the two other rock types. While the loss of mass of Andesite-3 reaches $40 \mathrm{~m} \%$ after 35 cycles of immersion in sulfate saturation and drying, the magnesium sulfate values of Andesite-1 and Andesite- 2 are less than $6 \mathrm{~m} \%$. Additionally, in the case of the separated fractions of Andesite-2, higher $M S$ values could be measured than the $M S$ values of Andesite-1, but the $M S$ of the complete $10.0 / 14.0 \mathrm{~mm}$ fraction of Andesite-2 is lower. This may occur because in the case of the 11.2/14.0 mm fraction of Andesite-2, relatively more grains weathered under $11.2 \mathrm{~mm}$, but relatively fewer grains weathered under $10 \mathrm{~mm}$ than in the case of the $11.2 / 14.0 \mathrm{~mm}$ fraction of Andesite-1.

The micro-Deval coefficients of the studied andesites showed significant differences. While the $M S$ values of Andesite- 1 and Andesite- 2 are about equal, the $M_{D E}$ value of Andesite- 1 is three times greater than the $M_{D E}$ of Andesite-2. The decay factor of the micro-Deval coefficient (Fig. 10) was calculated to investigate the effects of the longterm magnesium sulfate test on the resistance to abrasion.

\section{Discussion}

According to the magnesium sulfate test results, the weight loss follows a linearly increasing tendency (Fig. 5, 6 and 7). The monotony of the alteration of the weight loss is also
Fig. 6 The long-term magnesium sulfate crystallisation tests of Andesite-2

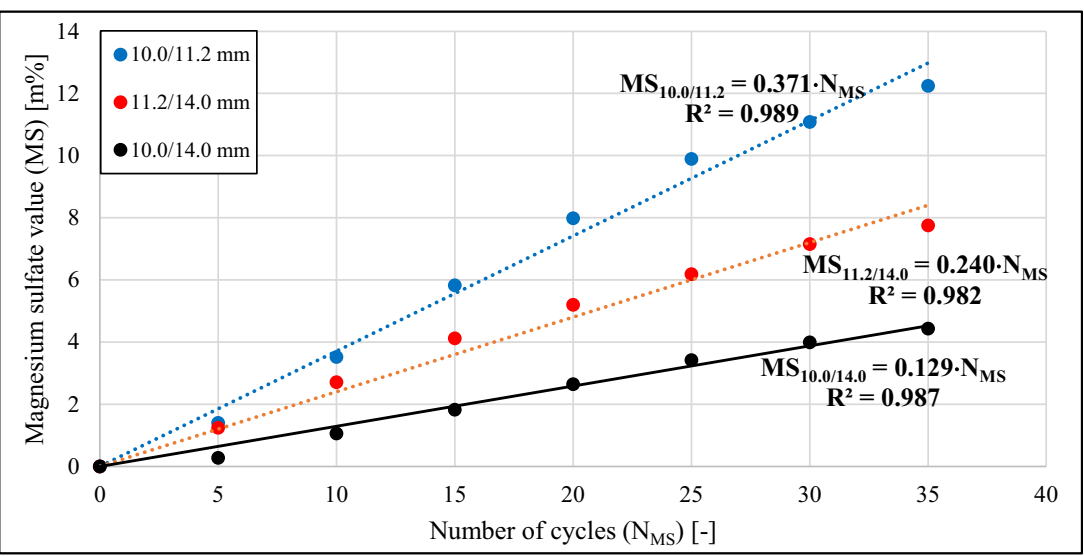


Fig. 7 The long-term magnesium sulfate crystallisation tests of Andesite-3

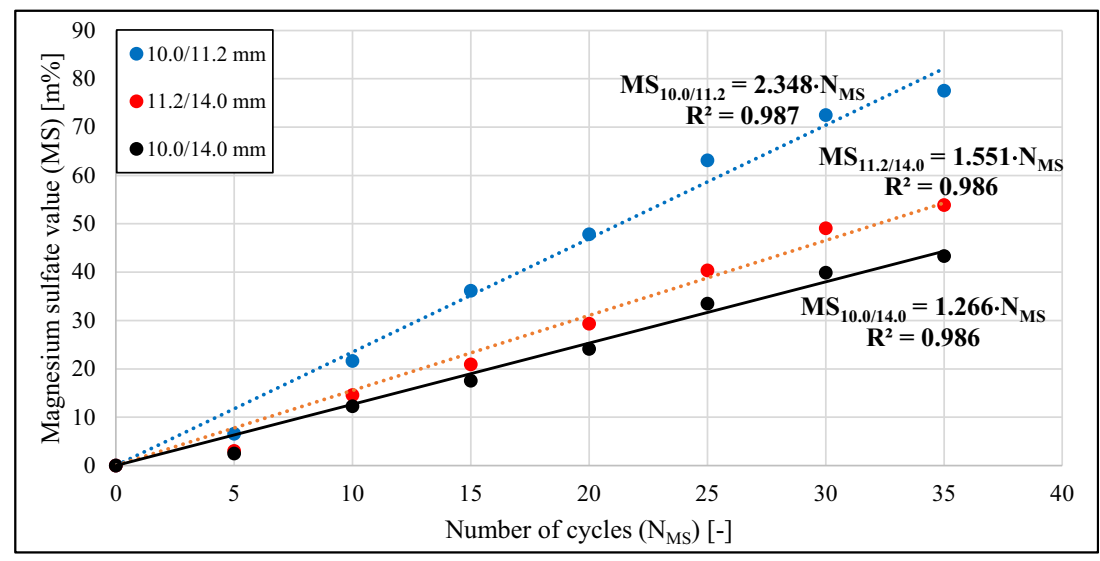

observed in the case of long-term freeze-thaw weathering tests of limestone, granite and lapilli tuff (Ruedrich et al. 2004). Bista and Tamrakar (2015) measured the weight loss of several rock types after every cycle of the magnesium sulfate test and found that weathering could be detected in all cases causing weight loss.

The long-term weathering properties of the rocks can be analysed by the repeat of the weathering effects such as freeze-thaw cycles of sulfate crystallisation tests. Thermal stresses can also reduce durability of granites (Vázquez et al. 2016; Freire-Lista and Fort 2017) sandstone (Sirdesai et al. 2017) and other lithologies, such as limestone (Brotóns et al. 2013) or marble (Martinho and Dionísio 2018). Akin and Özsan (2011) studied the mechanical and physical parameters of a Turkish travertine exposing cubic tests specimens to 80 cycles of freezing-thawing and 25 cycles of sulfate crystallization tests, while Jamshidi et al. 2016 made similar tests on Gerdoee travertine from Iran. Both studies emphasized the decreasing strength and durability of travertine and mostly decreasing trends with increasing number of stress cycles. The mechanical properties, e.g. the Young's modulus (1400 F-T cycles; Ruedrich et al. 2011) or the uniaxial compressive strength (UCS) (50 F-T cycles; Yavuz 2011), also followed decreasing tendencies through the repeat of the

Table 5 Micro-Deval test results

\begin{tabular}{llll}
\hline Number of cycles & \multicolumn{2}{l}{ Micro-Deval coefficient } \\
\hline$\left(\mathrm{N}_{\mathrm{MS}}\right)[-]$ & $\left(\mathrm{M}_{\mathrm{DE}}\right)[\mathrm{m} \%]$ & & \\
& Andesite-1 & Andesite- 2 & Andesite-3 \\
0 & 14.64 & 4.80 & 14.65 \\
5 & 15.88 & 4.82 & 19.05 \\
10 & 15.67 & 4.81 & 19.98 \\
15 & 15.97 & 4.98 & 19.74 \\
20 & 15.87 & 4.77 & 19.34 \\
25 & 15.51 & 4.54 & 17.53 \\
30 & 15.73 & 4.57 & 16.38 \\
35 & 15.36 & 4.62 & 15.73 \\
\hline
\end{tabular}

freeze-thaw cycles. The sulfate crystallisation tests of the tested andesites do not follow the same gradual decrease when not only the weight loss, as it is required by EN 1367-2, but the resistance against abrasion (micro-Deval values) are also considered (Table 5).

In the initial phase of the long-term magnesium sulfate test, the resistance to abrasion shows a decreasing tendency; in the case of Andesite-3, the reduction of it exceeded 30\% after 10 cycles of the sulfate test (Fig. 8). On the other hand, the maximal value of $\lambda_{M D E}$ was reached after 10-15 cycles (Fig. 10), and hence the degree of the decay reduced. Moreover, the micro-Deval coefficients of Andesite-2 changed to more favourable values than the reference value after 20 cycles (Table 5, Fig. 10). The unsteady trend of the alteration of the $M_{D E}$ values may be explained by the heterogeneity of the rock materials; the less resistant parts of the samples were weathered first, which caused increasing tendency of $\lambda_{M D E}$. After the degradation of these parts of the aggregates, only the more resistant grains remained in the samples, so the micro-Deval values started to approximate and even exceed the initial reference $M_{D E}$ values. It should be mentioned that the initial micro-Deval coefficient of Andesite- 2 is a relatively small number $(4.80 \mathrm{~m} \%)$ and thus small changes in absolute values $(0 . X X \mathrm{~m} \%)$ cause higher changes in the decay factors (Fig. 10). This leads to a decrease of micro-Deval coefficient, namely a better resistance $\left(\mathrm{M}_{\mathrm{DE}}=\right.$ $4.54 \mathrm{~m} \%$ after 25 cycles). Similar trends were observed at Andesite-1 and Andesite-3 samples; however, the decreased $M_{D E}$ values were still higher than the initial $M_{D E}$ values (Fig. 8 and Fig. 10).

This type of 'anomalous' behaviour is not very common; however, it was noted by Akin and Özsan 2011 that long-term freeze-thaw cycles might cause a slight increase in $\mathrm{P}$ wave velocity. According to Yavuz and Topal (2007) the uniaxial compressive strength of two types of marbles decreased after a few cycles of the sodium sulfate test, but after that, an increasing tendency could be measured. An extremely high value of UCS was measured on marble with $34 \%$ dolomite content after salt attack compared to the reference sample set. 
Fig. 8 The micro-Deval test results and the number of cycles

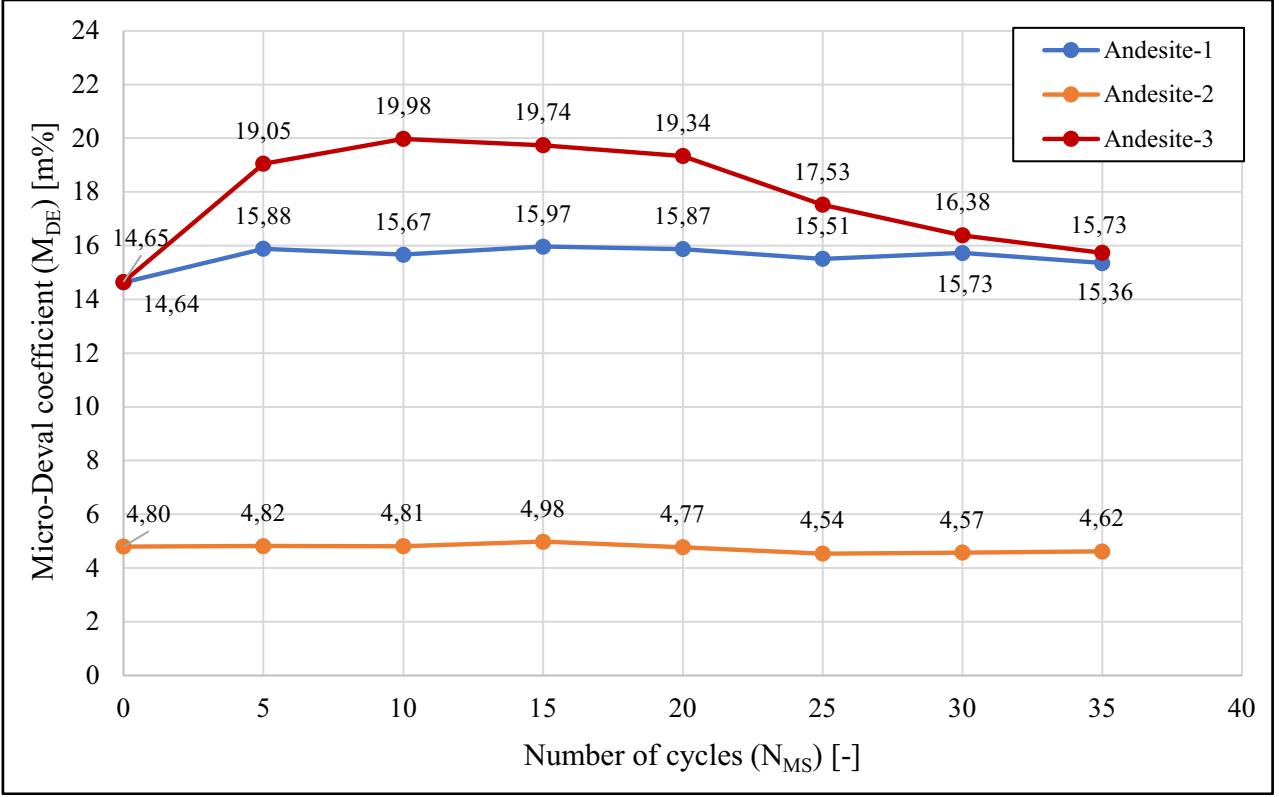

Nevertheless, most of the laboratory test results showed permanent decay of the studied properties: the UCS of sandstones (Khanlari et al. 2015) and the Brazilian tensile strength of a travertine (Jamshidi et al. 2016) when these samples were subjected to freeze-thaw. The slake durability index of a sandstone (Ghobadi and Babazadeh 2015) and the UCS of marbles (Yavuz and Topal 2007) subjected by salt crystallization was reduced. Although the aforementioned test results of these studies are similar to the results of the present study, similar trends were documented, and the results can not be directly compared since in those papers cuboid sedimentary rock specimens were used and other properties were also measured.

It should also be mentioned that the mineralogical and sedimentological properties of the stones can affect the mechanical (Yılmaz et al. 2011; Přikryl 2013; Khanlari et al. 2015), the aggregate (Räisänen 2004; Pang et al. 2010; Rigopoulos et al. 2013; Y1lmaz et al. 2015) and the weathering properties (Kazi and Al-Mansour 1980). The amount of the aluminum and iron oxides in the tested rocks can modify the durability of aggregates, namely the magnesium sulfate values (Tuğrul and Y1lmaz 2012). Our tests results imply that the different behaviour of the studied andesites is also partly linked to the differences in mineral content - namely, the slightly silicified pyroxene (Andesite-2) has the highest resistance against salt crystallisation. Indeed after 20 magnesium sulfate crystallisation cycles, its micro-Deval coefficient became lower than that of the original sample (Table 5, Fig. 8). The greatest loss in micro-Deval coefficient was observed after 15 sulfate crystallisation cycles at Andesite-3, which has amphiboles. The amphibole is a sensitive mineral to weathering, and it can adversely affect the durability of aggregates (Anastasio et al. 2016).

The micro-fabric, micro-cracks (Freire-Lista et al. 2015), pore sizes and the interconnections of pores significantly influence the durability and weathering properties of rocks (Tuğrul 2004; Török 2006; Yu and Oguchi 2010; Přikryl 2013; Pápay and Török 2015) and the efficiency of salt solution saturation (Çelik and Aygün 2018). The micro-fabric and
Fig. 9 The long-term magnesium sulfate test results of the 10.0/ $14.0 \mathrm{~mm}$-sized samples (Andesite-1, -2, -3)

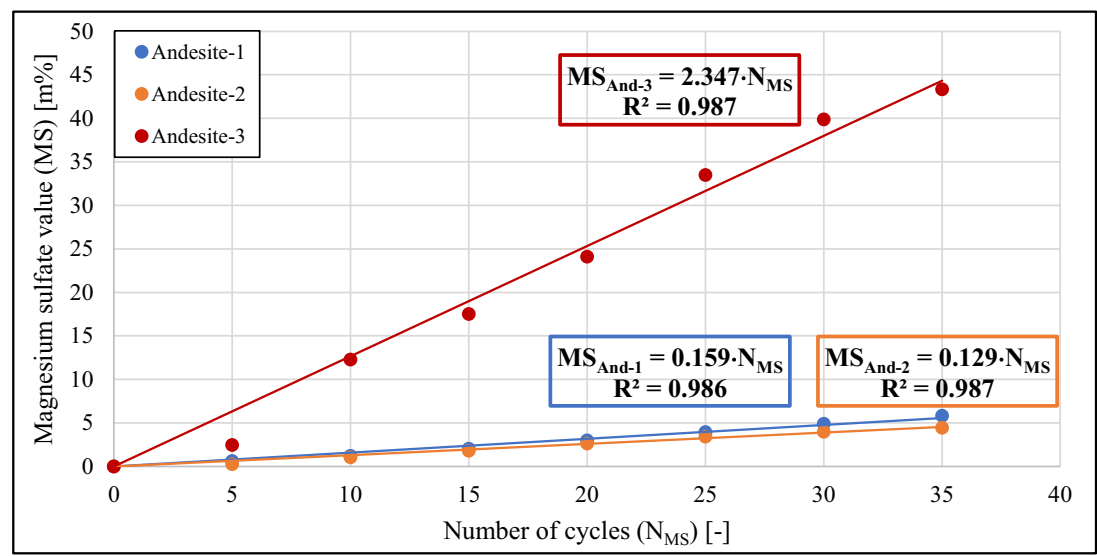


Fig. 10 The alteration of the micro-Deval coefficients according to the number of cycles (Andesite-1, -2, -3)

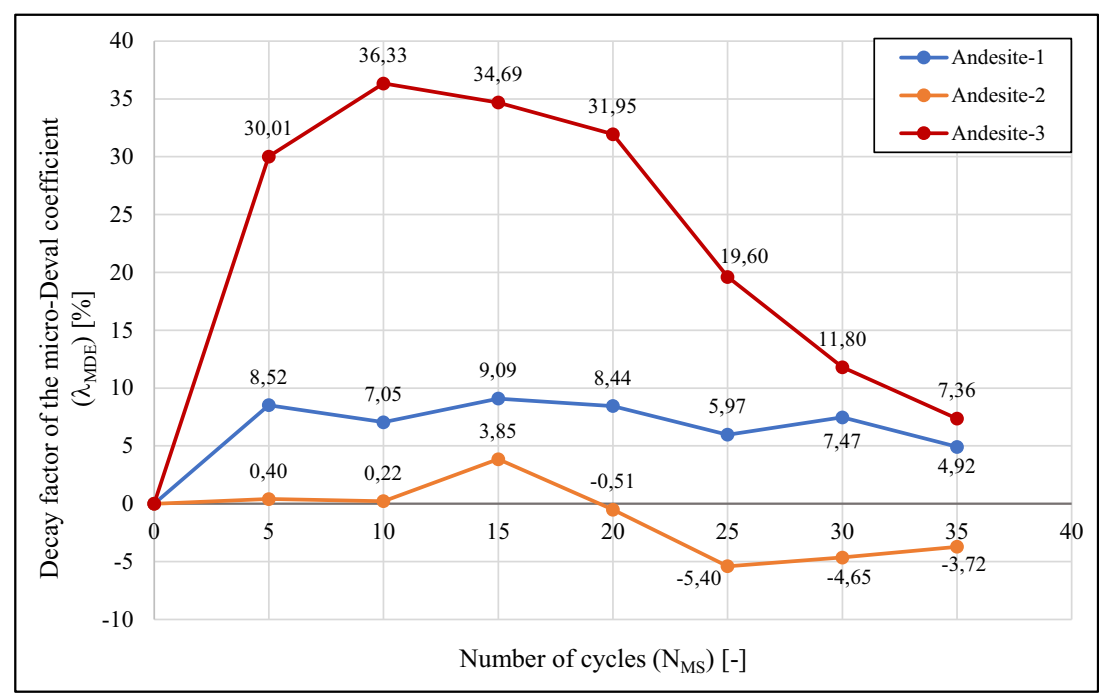

mineralogy controls the salt crystallisation durability and micro-Deval coefficient of the studied andesites, too. Explicitly, Andesite-2 and Andesite-3 have similar micro-fabric, but the slicification of Andesite-2 resulted in higher resistance against salt crystallisation and lower micro-Deval coefficient (Fig. 8). It seems that larger plagioclase phenocrysts (in Andesite-1) do not significantly increase the micro-Deval coefficient with increasing number of salt crystallisation cycles, when the results are compared with Andesite-3 (Fig. 9).

\section{Conclusions}

The regulations and standards require the determination of the resistance to salt crystallization of the aggregates. According to the relevant standard, the aggregate samples should be immersed in magnesium sulfate solution and be dried; then this cycle is repeated five times according to EN. The present study focused on the long-term weathering properties of andesite aggregates, and the cycles of the salt crystallization test was increased to 35. The mechanical-technical performances were measured by micro-Deval tests.

The weight loss of the samples follows linear trends in the course of the long-term tests. Greater magnesium sulfate values can be determined on the samples with smaller grains, which can be explained by the greater relative area of the surface of them. The micro-Deval tests performed parallel to the experiment showed that the equality of the magnesium sulfate values of different andesite aggregates does not mean the equality of the micro-Deval coefficients as well, and that the interrelation between them are not predictable in all cases. The tests also revealed that the salt crystallization may cause a loss in the resistance to abrasion, up to $35 \%$. The degree of loss depends on the studied material. Our experiments showed that the micro-Deval coefficients of the andesite from Recsk did not change significantly, due to its micro-fabric, i.e. silicified andesite. The decay factor of the micro-Deval coefficient increased at the initial part of the long-term tests in all cases, but after a certain number of cycles of the salt test, the decay factor declined. The reason for this is the heterogeneity of rock materials; the less resistant parts of the samples weathered first, and after that, only the more resistant parts remained in the aggregate samples.

Acknowledgements Open access funding provided by Budapest University of Technology and Economics (BME). The authors are beholden to Zita Kárpátiné Pápay, Gyula Emszt and Bálint Pálinkás for the advice and help in the laboratory tests, just as to László Ézsiás (COLAS Északkő Ltd.) and János Bobály (KÖKA Kö- és Kavicsbányász Ltd.) for providing andesite samples for the laboratory tests. The financial support of National Research, Development and Innovation (NKFI) Fund (ref. no. $\mathrm{K}$ 116532) is appreciated. The research reported in this paper was also supported by the BME-Water Sciences \& Disaster Prevention FIKP grant of EMMI (BME FIKP-VÍZ).

Open Access This article is distributed under the terms of the Creative Commons Attribution 4.0 International License (http:// creativecommons.org/licenses/by/4.0/), which permits unrestricted use, distribution, and reproduction in any medium, provided you give appropriate credit to the original author(s) and the source, provide a link to the Creative Commons license, and indicate if changes were made.

\section{References}

Ajalloeian R, Kamani M (2017) An investigation of the relationship between Los Angeles abrasion loss and rock texture for carbonate aggregates. Bull Eng Geol Env. https://doi.org/10.1007/s10064$017-1209-\mathrm{y}$

Akin M, Özsan A (2011) Evaluation of the long-term durability of yellow travertine using accelerated weathering tests. Bull Eng Geol Environ 70:101-114. https://doi.org/10.1007/s10064-010-0287-x

Anastasio S, Pérez-Fortes A, Scibilia E, Danielsen W (2016) Relevant petrological properties and their repercussions on the final use of aggregates. Energy Procedia 97:546-553. https://doi.org/10.1016/j. egypro.2016.10.073 
Bista K, Tamrakar NK (2015) Evaluation of strength and durability of rocks from Malekhu-Thopal Khola area, Central Nepal lesser Himalaya for construction aggregates. Bull Department of Geology, Tribhuvan University, Kathmandu, Nepal 18:15-34

Brotóns V, Tomás R, Ivorra S, Alarcon JC (2013) Temperature influence on the physical and mechanical properties of a porous rock: San Julian's calcarenite. Eng Geol 167:117-127. https://doi.org/10. 1016/j.enggeo.2013.10.012

Çelik MY, Aygün A (2018) The effect of salt crystallization on degradation of volcanic building stones by sodium sulfates and sodium chlorides. Bull Eng Geol Env, 21 p. doi:https://doi.org/10.1007/ s10064-018-1354-y

Cooley LA, James RS (2003) Micro-Deval testing of aggregates in the southeast. Trans Res Rec 1837:73-79. https://doi.org/10.3141/ 1837-08

Cserny T, Thamóné Bozsó E, Király E, Musitz B, Maros Gy, KovácsPálffy P, Bartha I (2004) Environmental geological studies of the road surface of highway M3. Annual Report of the Hung Geol Inst, Budapest: 239-252 (in Hungarian with English abstract)

Cuelho E, Mokwa R, Obert K, Miller A (2008) Comparative analysis of micro-Deval, L.a. abrasion and sulfate soundness test. TRB $87^{\text {th }}$ annual meeting compendium of papers DVD. Conference paper, Transportation Research Board $87^{\text {th }}$ annual meeting, Washington DC, 2008, p 17

EN 1097-1:2012 (2012) Tests for mechanical and physical properties of aggregates. Part 1: Determination of the resistance to wear (microDeval), p 15

EN 1367-1:2007 (2007) Tests for thermal and weathering properties of aggregates. Part 1: Determination of resistance to freezing and thawing, $\mathrm{p} 13$

EN 1367-2:2010 (2010) Tests for thermal and weathering properties of aggregates. Part 2: Magnesium sulfate test, $\mathrm{p} 16$

EN 12371:2010 (2010) Natural stone test methods. Determination of frost resistance, $\mathrm{p} 16$

Freire-Lista DM, Fort R, Varas-Muriel MJ (2015) Freeze-thaw fracturing in building granites. Cold Reg Sci Technol 113:40-51. https://doi. org/10.1016/j.coldregions.2015.01.008

Freire-Lista D, Fort R (2017) Exfoliation microcracks in building granite. Implications for anisotropy. Eng Geol 220:85-93. https://doi.org/10. 1016/j.enggeo.2017.01.027

Gálos M, Kárpáti L (2007) Testing of Hungarian aggregates for railway ballast according to MSZ EN 13450:2003. Cent Eur Geol 50(4): 353-361. https://doi.org/10.1556/CEuGeol.50.2007.4.5

Ghobady MH, Babazadeh R (2015) An investigation on the effect of accelerated weathering on strength and durability of tertiary sandstones (Qazvin province, Iran). Environ Earth Sci 73:4237-4250. https://doi.org/10.1007/s12665-014-3708-5

Haas J (2013) Geology of Hungary. Springer, Berlin, pp 1-246. https:// doi.org/10.1007/978-3-642-21910-8

Ioannou I, Fournari R, Petrou MF (2013) Testing the soundness of aggregates using different methodologies. Cons Build Mat 40:604 610. https://doi.org/10.1016/j.conbuildmat.2012.11.047

Jamshidi A, Nikudel MR, Khamehchiyan M (2016) Evaluation of the durability of Gerdoee travertine after freeze-thaw cycles in fresh water and sodium sulfate solution by decay function models. Eng Geol 202:36-43. https://doi.org/10.1016/j.enggeo.2016.01.004

Kazi A, Al-Mansour ZR (1980) Influence of geological factors on abrasion and soundness characteristics of aggregates. Eng Geol 15(3-4): 195-203. https://doi.org/10.1016/0013-7952(80)90034-4

Khanlari G, Sahamieh RZ, Abdilor Y (2015) The effect of freeze-thaw cycles on physical and mechanical properties of upper red formation sandstones, central part of Iran. Arab J Geosci 8:5991-6001. https:// doi.org/10.1007/s12517-014-1653-y

Klespitz J (2012) Quarry-geological observations in the Komló andesite pit. Építőanyag 64:18-21. https://doi.org/10.14382/epitoanyagjsbcm.2012.3 (in Hungarian with English abstract)
Krutilová K, Přikryl R (2017) Relationship between polished stone value (PSV) and Nordic abrasion value (AN) of volcanic rocks. Bull Eng Geol Environ 76:85-99. https://doi.org/10.1007/s10064-015-0814$\mathrm{x}$

La Iglesia A, González V, López-Acevedo V, Viedma C (1997) Salt crystallization in porous construction materials I - estimation of crystallization pressure. J Crys Gro 177:111-118. https://doi.org/ 10.1016/S0022-0248(96)01072-X

Martinho E, Dionísio A (2018) Assessment techniques for studying the effects of fire on stone materials: a literature review. Int J Architect Herit 1-25. doi:https://doi.org/10.1080/15583058.2018.1535008

Miščević P, Vlastelica G (2011) Durability characterization of marls from the region of Dalmatia, Croatia. Geotech Geol Eng 29:771-781. https://doi.org/10.1007/s10706-011-9416-y

Muthusamy K, Kamaruzzaman NW, Zubir MA, Hussin MW, Sam ARM, Budiea A (2015) Long term investigation on sulphate resistance of concrete containing laterite aggregate. Process Eng 125:811-817. https://doi.org/10.1016/j.proeng.2015.11.145

Mutlutürk M, Altindag R, Türk G (2004) A decay function model for the integrity loss of rock when subjected to recurrent cycles of freezing thawing and heating-cooling. Int J Rock Mech Min Sci 41:237244. https://doi.org/10.1016/S1365-1609(03)00095-9

Özden UA, Topal T (2009) Evaluation of andesite source as armourstone for a rubble mound breakwater (Hisarönü, Turkey). Environ Earth Sci 59:39-49. https://doi.org/10.1007/s12665-009-0002-z

Pang L, Wu S, Zhu J, Wan L (2010) Relationship between petrographical and physical properties of aggregates. J Wuhan Univ Technol Mater Sci Ed 25:678-681. https://doi.org/10.1007/s11595-010-0069-0

Pápay Z, Török Á (2015) Micro-fabric, pore-size distribution and water absorption of consolidated porous limestone. In: Lollino G., Giordan, D., Marunteanu C., Christaras B., Yoshinori I., Margottini C. (eds.) Engineering Geology for Society and Territory - Volume 8: Preservation of cultural heritage. 12th IAEG congress, Torino, Springer Switzerland, pp 553-556

Piasta W, Góra J, Turkiewicz T (2016) Properties and durability of coarse igneous rock aggregates and concretes. Const Build Mat 126:119 129. https://doi.org/10.1016/j.conbuildmat.2016.09.022

Phillips WF (2000) Comparative analyses between the magnesium sulfate soundness and micro-Deval tests in the evaluation of bituminous aggregates. MSc thesis, Texas Tech University, Lubbock

Přikryl R (2013) Durability assessment of natural stone. Q J Eng Geol Hydrogeol 46:377-390. https://doi.org/10.1144/qjegh2012-052

Přikryl R (2017) Constructional geomaterials: versatile earth resources in the service of humankind - introduction to the thematic set of papers on: challenges to supply and quality of geomaterials used in construction. Bull Eng Geol Environ 76:1-9. https://doi.org/10.1007/ s10064-016-0985-0

Räisänen M (2004) Relationships between texture and mechanical properties of hybrid rocks from the Jaala-Iitti complex, southeastern Finland. Eng Geol 74:197-211. https://doi.org/10.1016/j.enggeo. 2004.03.009

Rigopoulos I, Tsikouras B, Pomonis P, Hatzipanagiotou K (2013) Determination of the interrelations between the engineering parameters of construction aggregates from ophiolite complexes of Greece using factor analysis. Const Build Mater 49:747-757. https://doi. org/10.1016/j.conbuildmat.2013.08.065

Ruedrich J, Kirchner D, Siegesmund S (2011) Physical weathering of building stones induced by freeze-thaw action: a laboratory longterm study. Environ Earth Sci 63:1573-1586. https://doi.org/10. 1007/s12665-010-0826-6

Ruiz-Agudo E, Mees F, Jacobs P, Rodriguez-Navarro C (2007) The role of saline solution properties on porous limestone salt weathering by magnesium and sodium sulfates. Environ Geol 52:269-281. https:// doi.org/10.1007/s00254-006-0476-x

Sirdesai N, Singh TN, Ranjith PG (2017) Thermal alterations in the poromechanical characteristic of an Indian sandstone - a comparative 
study. Eng Geol 226:208-220. https://doi.org/10.1016/j.enggeo. 2017.06.010

Török Á (2006) Influence of fabric on the physical properties of limestones. In: Kourkoulis SK (ed) Fracture and failure of natural building stones. Springer, Dordrecht, pp 487-495

Török Á (2015) Los Angeles and micro-Deval values of volcanic rocks and their use as aggregates, examples from Hungary. In: Lollino G, Manconi A, Guzzetti F, Culshaw M, Bobrowsky P, Luino F (eds) Engineering Geology for Society and Territory - Volume 5: Urban geology, sustainable planning and landscape exploitation. 12th IAEG congress, Torino. Springer Switzerland, pp 115-118

Török Á, Czinder B (2017) Relationship between density, compressive strength, tensile strength and aggregate properties of andesites from Hungary. Environ Earth Sci 76:639. https://doi.org/10.1007/s12665017-6977-y

Tuğrul A (2004) The effect of weathering on pore geometry and compressive strength of selected rock types from Turkey. Eng Geol 75: 215-227. https://doi.org/10.1016/j.enggeo.2004.05.008

Tuğrul A, Yılmaz M (2012) Assessing the quality of sandstones for use as aggregate in concrete. Mag Concrete Res 64(12):1067-1078. https://doi.org/10.1680/macr.11.00179

Vázquez P, Acuña M, Benavente D, Soizic G, Navarro I, Gomez-Heras M (2016) Evolution of surface properties of ornamental granitoids exposed to high temperatures. Constr Build Mater 104:263-275. https://doi.org/10.1016/j.conbuildmat.2015.12.051

Wongprachum W, Sappakittipakorn M, Sukontasukkul P, Chindaprasirt P, Banthia N (2018) Resistance to sulfate attack and underwater abrasion of fiber reinforced cement mortar. Const Build Mat 189: 686-694. https://doi.org/10.1016/j.conbuildmat.2018.09.043
Xie X, Wang D, Liu D, Zhang X, Oeser M (2016) Investigation of synthetic, self-sharpening aggregates to develop skid-resistant asphalt surfaces. Wear 348-349:52-60. https://doi.org/10.1016/j.wear.2015. 11.0220

Yavuz H, Altindag R, Sarac S, Ugur I, Sengun N (2006) Estimating the index properties of deteriorated carbonate rocks due to freeze-thaw and thermal shock weathering. J Rock Mech Min Sci 43:767-775. https://doi.org/10.1016/j.ijrmms.2005.12.004

Yavuz H (2011) Effect of freeze-thaw and thermal shock weathering on the physical and mechanical properties of an andesite stone. Bull Eng Geol Environ 70:187-192. https://doi.org/10.1007/s10064010-0302-2

Yavuz H, Topal T (2007) Thermal and salt crystallization effects on marble deterioration: examples from Western Anatolia, Turkey. Eng Geol 90:30-40. https://doi.org/10.1016/j.enggeo.2006.11.005

Yllmaz M, Tugrul A, Karasahin M, Boz I (2015) Assessing the stripping properties of granite aggregates in bituminous mixtures. Bull Eng Geol Environ 74:673-682. https://doi.org/10.1007/s10064-0140631-7

Yılmaz NG, Goktan RM, Kibici Y (2011) Relations between some quantitative petrographic characteristics and mechanical strength properties of granitic building stones. Int J Rock Mech Min Sci 48:506513. https://doi.org/10.1016/j.ijrmms.2010.09.003

Yu S, Oguchi CT (2010) Role of pore size distribution in salt uptake, damage, and predicting salt susceptibility of eight types of Japanese building stones. Eng Geol 115:226-236. https://doi.org/10.1016/j. enggeo.2009.05.007 